\title{
Analisis Return on Equity dan Debt to Equity Ratio
}

\author{
Sufriani \\ Sekolah Tinggi Ilmu Ekonomi \\ Bima \\ Kota Bima, Indonesia \\ sufriani16stiebima@gmail.com
}

\author{
M. Rimawan \\ Sekolah Tinggi Ilmu Ekonomi \\ Bima \\ Kota Bima, Indonesia \\ rimawan111@gmail.com
}

Corresponding Author : Sufriani

Submitted: 3 April 2020

Accepted: 30 Juni 2020

Published: 1 Agustus 2020

\begin{abstract}
ABSTRAK
Penelitian ini bertujuan untuk mengetahui dan menganalisis Rasio profitabilitas menggunakan Return on Equity dimana membandingkan antara laba setelah pajak dan Ekuitas dan Rasio Solvabilitas menggunakan Debt To Equty Ratio dimana membandingkan total hutang dengan ekuitas pada PT Adaro Energy Tbk dimana semakin tinggi nilai Return on Equity maka semakin tidak baik perusahaan dalam mengelola modal sendiri untuk menghasilakn Laba begitu juga sebaliknya apabila nilai Return on Equity rendah semakin baik. Sedangkan Debt to Equity Ratio tinggi maka pengelolaan ekuitas tidak baik apabila Debt to Equity Ratio rendah maka penggunaan modal sendiri sangat baik karna tidak mengandalkan pendaanaan dari luar. Penelitian ini adalah penelitian Deskriptif dimana hanya menbandingkan 1 satu variabel saja. Populasi dalam penelitian ini adalah 11 tahun dan sampel dalam penelitian ini selama 9 tahun mulai 2010 sampai tahun 2018 dengan sampling yang digunakan adalah purposive sampling. Uji statistik mengunakan SPSS v 21 dengan teknik analisis data menggunakan metode one sample t-test. hasil penelitian menunjukan bahwa Return on Equity dikatakan baik dan Debt to Equity Ratio dikatakan baik.. Ini menunjukan bahwa pengelolaan modal sendiri sudah sangat baik karena tidak mengandalkan modal dari pihak luar dan sudah dapat meningkatkan Laba

Kata Kunci : Return on Equity, Debt to Equity Ratio
\end{abstract}

\section{PENDAHULUAN}

Persaiangan perusahaan di Era sekarang yang di tandai dengan majunya perekonomian Indonesai saat ini, mengharuskan perusahaan untuk dapat lebih meningkatkan kinerjanya agar dapat bertahan didalam menghadapi pertumbuhan dan perkemabnagan perekonomian yang selalu berubah dengan cepat dan dinamis. Kinerja menjadi hal penting yang harus dicapai oleh setiap perusahaan karena kinerja menjadi acuan atau gambaran setiap perusahaan untuk prestasi dan pancapaian suatu perusahaan.
Laporan keuangan merupakan laporan yang mampu menunjukkan perkembangan posisi finansial dan mempunyai arti yang penting bagi perusahaan karena laporan keuangan pada perusahaan dapat mencerminkan kinerja yang telah tercapai pada suatu waktu dan untuk melihat kesanggupan perusahaan dalam menanggulangi masalah keuangan serta menentukan keputusan yang tepat serta laporan keuangan juga dapat mengambarkan seberapa besar perolehan profit pada suatu entitas pada kurun waktu tertentu. (Zainal \& Marlius, 2018) 
Kinerja perusahaan dapat kita lihat dari Laba operasional, laba bersih persaham dan rasio- rasio keuangan yang menunjukan kemapuan manajemen dalam mengelola perusahaan. Rasio keuangan yang dapat digunakan untuk mengukur kinerja perusahaan diantaranya yaitu rasio likuiditas, rasio profitabilitas, rasio aktivitas dan rasio solvabilitas.

Rasio keuangan adalah suatu kegiatan membandingkan angka yang ada dalam komponen laporan keuangan, angka yang di bandingkan dapat berupa angka dalam satu periode tertentu atau beberapa periode. Rasio yang sering digunakan dalam rasio keuangan meliputi rasio likuiditas, solvabilitas, aktivitas dan profitabilitas. Analisa rasio merupakan metode untuk mengetahui hubungan dari pos-pos yang ada dalam laporan keuangan seperti nerac dan laporan rugi laba secara individu atau kombinasi (Adriani, Rizki, \& dkk, 2015)

Analisis rasio keuangan sangat penting gunanya untuk melakukan evaluasi terhadap kondisi keuangan perusahaan. Dengan mengetahui tingkat likuiditas perusahaan, untuk mengetahui kemampuan perusahaan dalam memenuhi kewajiban jangka pendeknya. Sedangkan dengan mengetahui tingkat leveragenya, dapat diketahui sejauh mana kemampuan perusahaan dalam melunasi seluruh utang-utangnya. Dan dengan mengetahui tingkat aktivitas perusahaan, maka dapat diketahui seberapa efektif manajemen perusahaan menggunakan aktiva yang dimilikinya dalam melaksanakan kegiatan perusahaan, serta dengan mengetahui tingkat profitnya perusahaan, sehingga dapat diketahui sejauh mana perusahaan dalam menghaslkan keuntungan secara efektif dan seberapa baik kinerja manajemen dalam mengelola perusahaan (Fahmi, 2015)

Return of equity (ROE) mencerminkan pengaruh dari seluruh rasio lain dan merupakan ukuran kinerja tunggal yang terbaik dilihat dari kacamata akuntansi. Investor sudah pasti menyukai nilai ROE yang tinggi, dan ROE yang tinggi umumnya memiliki kolerasi yang positif dengan harga saham yang tinggi. Namun ada beberapa faktor lain lagi yang terlibat. (Houston \& Brigham, 2017)

Debt to Equity Ratio merupakan salah satu aspek yang dinilai dalam mengukur kinerja perusahaan adalah aspek solvabilitas atau hutang perusahaan. Hutang merupakan komponen penting perusahaan khususnya sebagai salah satu sarana pendanaan. Sering terjadi penurunan kinerja perusahaan disebabkan besarnya utang yang dimiliki perusahaan sehingga kesulitan dalam memenuhi kewajiban tersebut (Komalasari, 2017) Rasio Debt to Equity Ratio merupakan rasio yang mengukur sejauh mana besarnya hutang dapat ditutupi oleh modal sendiri. Apabila DER Tinggi menunjukkan semakin besar kepercayaan dari pihak luar, hal ini sangat memungkinkan meningkatkan kinerja keuangan perusahaan, karena dengan modal yang besar maka kesempatan untuk meraih tingkat keuntungan juga besar sehingga dalam dapat menunjukkan kinerja perusahaan yang baik. (Armin, 2019)

PT. Adaro Indonesia yang berdiri tahun 1982 adalah anak perusahaan dari PT Adaro Energy Tbk, dan merupakan perusahaan pertambangan yang melakukan kegiatan eksplorasi serta penambangan batubara. Lokasi kantor operasional berada di Tanjung, Provinsi Kalimantan Selatan. Sedangkan lokasi penambangan terletak di Kabupaten balangan dan Kabupaten Tabalong di Kalimantan Selatan. Sedangkan tempat penumpukan batubara (crushing plant) beserta pelabuhan muat terletak di Kabupaten Barito Selatan di Kalimantan Tengah

Berikut merupakan perkembangan Return On Equity pada PT Adaro Energy Tbtk selama kurun waktu 10 tahun: 
Tabel 1: Return on Equity PT Adaro

\begin{tabular}{|c|c|c|c|}
\hline Tahun & $\begin{array}{c}\text { Total } \\
\text { Hutang }\end{array}$ & Ekuitas & DER \\
\hline 2010 & 2.440 .000 & 2.063 .000 & 118,27 \\
\hline 2011 & 3.216 .738 & 2.442 .223 & 131,71 \\
\hline 2012 & 3.679 .202 & 2.995 .054 & 122,84 \\
\hline 2013 & 3.538 .784 & 3.195 .003 & 110,76 \\
\hline 2014 & 3.155 .500 & 3.258 .148 & 96,85 \\
\hline 2015 & 2.605 .586 & 3.353 .043 & 77,71 \\
\hline 2016 & 2.736 .375 & 3.785 .882 & 72,28 \\
\hline 2017 & 2.722 .520 & 4.091 .627 & 66,54 \\
\hline 2018 & 2.758 .063 & 4.302 .692 & 64,10 \\
\hline \multicolumn{4}{|c}{ Energy Tbk } \\
\hline
\end{tabular}

Tahun 2010-2018

\begin{tabular}{|c|c|c|c|}
\hline Tahun & EAT & Ekuitas & ROE \\
\hline 2010 & 247,369 & $2,032,211$ & 12.17 \\
\hline 2011 & 559,500 & $2,442,223$ & 22.91 \\
\hline 2012 & 383,307 & $2,995,054$ & 12.80 \\
\hline 2013 & 229,263 & $3,195,003$ & 7.18 \\
\hline 2014 & 183,540 & $3,258,148$ & 5.63 \\
\hline 2015 & 151,003 & $3,353,043$ & 4.50 \\
\hline 2016 & 340,686 & $3,785,882$ & 9.00 \\
\hline 2017 & 536,438 & $4,091,627$ & 13.11 \\
\hline 2018 & 477,541 & $4,302,692$ & 11.10 \\
\hline
\end{tabular}

Sumber : data diolah

Berdasarkan data diatas bisa di bilang Return On Equity PT Adaro Energy Tbk mengalami fluktuatif, apabila dibandingkan dengan Standar Return On Asset ini bisa dikatakan tidak baik karena rata industry yang digunakan adalah $10 \%$

Debt to Quity Ratio ini dapat menggambarkan kemampuan peruhasaan didalam menjalankan kegiatanya lebih banyak mengguakan modal sendiri dari pada dana dari pihak ketiga atau melakaukan peminjam kepada kreditur atau Bank, berdasarkan standar industri Debt to Equity Ratio menggunakan standar $90 \%$ semakin tinggi rasio ini semakin besar perusahan menggunakan modal dari luar dan semakin rendah DER maka semakin sedikit perusahaa menggunakan modal dari luar

Berikut ini merupakan perkembangan Debt To Equity Ratio pada PT Adaro Energy Tbk Kurun waktu 10 Tahun
Tabel 2: Debt To Equity Ratio

Tahun 2010-2018

Sumber : data diolah

Berdasarkan data di atas bisa dikatakan bahwa Debt To Equity Rasio PT Energi Tbk mengalami fluktuatuf, apabila dibandingkan dibandingkan dengan Standar Debt to Equity Ratio ini bisa dikatan tidak baik karena standar DER 90\% dan bisa kita liah juga bagaimana selama 5 tahun mulai tahun 2010 sampai 2014 menunjukan bahwa penggunaaan utang lebih besar daripada Modal sendiri, tetapi di tahun 2015 sampai 2018 dikatakan baik karena perusahaan ini menggunkan modal sendiri lebih besar dari pada hutang.

Salah satu rasio untuk menilai prestasi perusahaan atau kinerja keuangan perusahaan merupakan rasio profitabilitas yang mengkaitkan dua tau lebih data keuangan yang satu dengan yang lainya. Rasio profitabilitas merupakan rasio yang memberikan petunjuk terkait tingkat imbalan atau perolehan (keuntungan) dibanding penjualan atau aktiva. "Rasio profitabilitas ini akan memberikan jawaban dari efektivitas manajemen perusahaan dan efektivitas pengelolaaan keuangan perusahaan (Yanti \& Oktari, 2018) maka dari itu perlu dilakukan analisis rasio profitabilitas pada PT Adaro Energy Tbk untuk melihat sejauh mana perusahaan melakukan efektivitas pengelolaan manajemen keuangan dilihat dari rasio yaitu Return On Equity dan Debt to Equty pada perusahaan PT Adaro Energy Tbk.

\section{TINJAUAN PUSTAKA}

\subsection{Analisa Laporan Keuangan}

Analisa laporan keuangan menunjukan keadaan keuangan serta hasil usaha perusahaan pada satu periode atau lebih dalam waktu tertentu. Ada beberapa laporan keuangan yang kita kenal yaitu Neraca, Laporan Rugi laba dan Arus kas, serta laporan catatan atas laporan keuangan (Kasmir, 2016) 
Pengertian laporan keuangan menurut Ikatan Akuntan Indonesia (2015) dalam Standar Akuntansi Keuangan (SAK) No. 1 dikemukakan bahwa Laporan keuangan merupakan bagian dari proses pelaporan keuangan dan laporan keuangan adalah suatu penyajian terstruktur dari posisi keuangan dan kinerja keuangan suatu entitas. Laporan keuangan yang lengkap biasanya meliputi neraca, laporan laba rugi, laporan perubahan posisi keuangan (yang dapat disajikan dalam berbagai cara misalnya, sebagai laporan arus kas, atau laporan arus dana), catatan dan laporan lain serta materi penjelasan yang merupakan bagian integral dari laporan keuangan. Di samping itu termasuk juga skedul dan informasi tambahan yang berkaitan dengan laporan tersebut, misalnya informasi keuangan segmen industri dan geografis serta pengungkapan pengaruh perubahan harga. (IAI, 2015)

Tujuan laporan keuangan adalah memberikan informasi mengenai posisi keuangan, kinerja keuangan, dan arus kas entitas yang bermanfaat bagi sebagian besar pengguna laporan keuangan dalam membuat keputusan ekonomi. Laporan keuangan ini merupakan sebagi wujud tangung jawab manajemen atas penggunaan sumber daya yang dipercayakan kepada merekadalam mengelola entitas perusahan. Dengan demikian laporan keuangan tidak dimaksudkan untuk tujuan khusus, misalnya dalam rangka likuidasi entitas atau menentukan nilai wajar entitas untuk tujuan merger dan akuisisi. Juga tidak disusun khusus untuk memenuhi kepentingan suatu pihak tertentu saja misalnya pemilik mayoritas. Pemilik adalah pemegang instrumen yang diklasifikasikan sebagai ekuitas. (Hans, 2016)

Tujuan laporan keuangan adalah menyediakan informasi yang menyangkut posisi keuangan, kinerja keunagan serta perubahan posisi keuangan suatu entitas yang bermanfaat bagi sejumlah besar pengguna dalam pengambilan keputusan ekonomi. Laporan keuangan yang disusun untuk tujuan ini memenuhi kebutuhan bersama sebagian besar pengguna. Namun demikian, laporan keuangan tidak menyediakan semua informasi yang mungkin dibutuhkan pengguna dalam pengambilan keputusan ekonomi karena secara umum menggambarkan pengaruh keuangan dari kejadian di masa lalu, dan tidak diwajibkan untuk menyediakan informasi non keuangan. (Hutahuruk, 2017)

\subsection{Rasio Profitabilitas}

Pada umumnya setiap perusahaan bertujuan untuk memperoleh laba atau keuntungan. Para manajemen perusahaan dituntut harus mampu mencapai target yang telah direncanakan. menurut Sartono dalam (Fatmawati, 2019) Profitabilitas merupakan kemampuan perusahaan dalam memperoleh laba dalam hubungannya dengan penjualan, total aktiva maupun modal sendiri. Umumya perusahaan lebih menyukai pendapatan yang mereka terima digunkan sebagai sumber utama dalam pembiayaan untuk investasi. Rasio profitabilitas merupakan rasio yang mengambarkan kemampuan perusahaan dalam menghasilkan laba melalui semua kemampuan dan sumber daya yang dimiliki yaitu yang berasal dari penjualan, penggunaan aset maupun modan dan biasanya rasio profitabilitas disesuaikan dengan tujuan dan kebutuhan perusahaan. (Hery, 2015)

\subsection{Return On Equity}

Return on Equity adalah suatu penilaian dari pengahsilan yang tersedian bagi suatu perusahaan baik itu saham biasa maupun saham presefen atas modal yang mereka investasikan didalam perusahaan (Syamsuddin, 2016)

Return on Equity (ROE) menurut (Harahap, 2015) Return on Equity merupakan perbandingan antara laba 
bersih sesudah pajak dengan total ekuitas. Return on Equity merupakan suatu pengukuran dari penghasilan (income) yang tersedia bagi para pemilik perusahaan (baik pemegang saham biasa maupun pemegang saham preferen) atas modal yang mereka investasikan di dalam perusahaan.

Rasio Return on Equity dapat dikatakan dengan laba atas equity rasio ini mengkaji sejauh mana suatu perusahaan menggunakan sumber daya yang dimiliki untuk mampu menghasilkan laba atas ekuitas (Fahmi, 2015)

Teori pengaruh Return on Equity terhadap harga saham adalah hasil pengembalian ekuitas atau return on equity atau rentabilitas modal sendiri adalah rasio untuk mengukur laba bersih setelah pajak dengan modal sendiri, rasio ini merupakan efisiensi dari penggunaan modal sendiri semakin tinggi rasio ini maka akan semakin bagus artinya posisi pemilik perusahaan semakin kuat demikian sebaliknya (Kasmir, 2016)

Apabila suatu perusahaan memperlihatkan suatu ROE yang tinggi dan konsisten, berarti perusahaan tersebut mengindikasikan mempunyai suatu keunggulan yang tahan lama dalam persaingan. Jika perusahaan dapat menghasilkan laba yang tinggi, maka permintaan saham akan meningkat dan selanjutnya akan berdampak pada meningkatnya harga saham perusahaan. Ketika harga saham semakin meningkat maka return saham juga akan meningkat. (Fransiska, 2014)

Debt to Equity Ratio dipergukan dalam mengukur kemampuan perusahaan membiayai total hutang mnggukan modal sendiri menutur(Rahmawati \& Suryono, 2017)

Return on Equity merupakan perbandingan antara laba bersih setelah pajak dan Total Equitas. (Wulandari \& Dkk, 2020) Rumusnya sebagai berikut $R O E=\frac{\text { laba bersih setelah pajak }}{\text { Ekuitas }} \times 100 \%$

\subsection{Debt to Equity Ratio}

Apabila nilai Debt to Equity ratio ini semakin tinggi ini menunjukan semakin tinggi pula jumlah dana dari luar yang harus dijamin oleh perusahaan dengan Jumlah Modal sendiri (Hani, 2015)

Menurut (Novita \& Herlambang, 2020) Debt to Equity Ratio merupakan rasio yang digunakan untuk mengukur kemampuan perusahaan membiayai Total hutang menggunkan Modal sendiri Indikator yang digunakan dalam mengitung Debt To Equity Ratio dinyatakan dengan Rumus:

Debt to Equity Ratio

$$
=\frac{\text { Total Liabilities }}{\text { Total Ekuitas }}
$$

Kriteria pengukuran Debt to Equity

\begin{tabular}{|c|c|}
\multicolumn{2}{|c}{ Ratio } \\
\hline Presentase & Keterangan \\
\hline$\leq 90 \%$ & Baik \\
\hline$>90 \%$ & Tidak Baik \\
\hline
\end{tabular}

Sumber : Kasmir

\section{METODE PENELITIAN}

\subsection{Jenis penelitian}

Dalam penelitian ini digunakan jenis penelitian deskriptif. Penelitian deskriptif merupakan penelitian yang digunakan untuk mengetahui nilai variabel mandiri, baik satu variabel atau lebih (independen) tanpa membuat perbandingan, atau menghubungkan antara variabel satu dengan variabel yang lain. (Sugiyono, 2016)

\subsection{Populasi}

Menurut (Sugiyono, 2016) populasi merupakan daerah yang digeneralisasi terdiri atas subjek dan objekyang mempunyai keterwakilan kualitas atau karakteristik tertentu yang ditetapkan oleh peneliti untuk dipelajari dan ditarik kesimpulanya.

Berdasarkan pendapat tersebut maka Populasi yang digugakan yaitu : data laporan keuangan laba/rugi ,terdiri dari laba besih setelah pajak dan laporan posisi 
keuangan yang terdiri dari data total ekuitas dan data total liabilitas. dalam annual report untuk memperoleh data jumlah return on equity dan Debt to equity Periode 2008 sampai dengan 2018 atau selama (11) tahun.

\subsection{Sampel}

Sampel yang digunakan adalah bagian dari jumlah dan karakteristik yang dimiliki oleh populasi tersebut. Berdasarkan populasi diatas maka sampel penelitian selama 9 tahun terakhir yaitu dari tahun 2010 sampai dengan tahun 2018. Karena data laba bersih setelah pajak, ekuitas dan hutang mengalami fluktuatif. tekhnik sampling adalah non probability sampling dengan menggunkan porpusive sampling dimana pertimbangannya adalah ; 1). Data terupdate 2). Peneliti merasa sampelnya bisa mewakili populasi 3). Ketersdiaan data mengenai variabel penelitian.

\subsection{Instrument penelitian}

Instrument dalam penelitian ini adalah suatu alat yang digunakan untuk mengukur variable dalam penelitian. (Sugiyono, 2016) Adapun alat yang digunakan dalam pengumpulan data adalah berupa daftar tabel, untuk tabulasi data laporan keuangan PT. Adaro Energy Tbk. Dari tahun 2014 sampai dengan tahun 2018 yang berkaitan dengan laba bersih setelah pajak. Total asset. Total hutang dan Total Ekuitas

\subsection{Analisis data}

Dalam penelitian ini, digunakan juga analisis data uji t satu pihak ( $t$-test One Sample). SPSS versi 21 (Ghozali, 2016). Teknik analisi ini digunakan karena variabel dalam penelitin ini adlaah hanya 1 variabel.

\section{HASIL DAN PEMBAHASAN}

\subsection{Return On Equity}

Dengan menggunakan Uji - $t$ test one sampel dengan nilai $\mu=10 \%$ serta tingkat signifikan 0,05 dapat dihitung sebagai berikut:

1. Standar Deviasi (s)

$$
\begin{aligned}
& S=\sqrt{\frac{\sum\left(X 1-\bar{X}^{2}\right.}{n-1}} \\
& S=\sqrt{\frac{241}{9-1}} \\
& S=\sqrt{\frac{241}{8}} \\
& S=\sqrt{30,125} \\
& S=5,479
\end{aligned}
$$

2. Uji-T

Uji-T atau One Sample T-Test Method, merupakan pengujian dengan menggunakan sampel tunggal dan rata-rata dibandingkan dengan nilai konstanta. Uji-t tersebut dapat dihitung dengan rumus sebagai berikut : Menghitung $\mathrm{T}$ test one sample (Uji T) adalah sebagai berikut:

$$
\begin{aligned}
& \mathrm{t} \text { hitung }=\frac{x-\mu 0}{\frac{s}{\sqrt{n}}} \\
& \mathrm{t} \text { hitung }=\frac{10.93-10}{\frac{5.479}{\sqrt{9}}} \\
& \mathrm{t} \text { hitung }=\frac{0.93}{1.8263} \\
& \mathrm{t} \text { hitung }=0,501
\end{aligned}
$$

Standar deviasi dan t hitung one sample test

\begin{tabular}{|c|c|c|c|c|}
\hline \multicolumn{5}{|c|}{ One-Sample Statistics } \\
\hline & $\mathrm{N}$ & $\begin{array}{c}\text { Mea } \\
\mathrm{n}\end{array}$ & $\begin{array}{c}\text { Std. } \\
\text { Deviati } \\
\text { on }\end{array}$ & $\begin{array}{c}\text { Std.Err } \\
\text { or } \\
\text { Mean }\end{array}$ \\
\hline ROE & 9 & $\begin{array}{c}10,9 \\
1\end{array}$ & 5,479 & 1,826 \\
\hline
\end{tabular}

Sumber : data dioleh dengan SPSS v21

\begin{tabular}{|c|c|c|c|c|c|}
\hline \multirow{2}{*}{} & \multicolumn{5}{|c|}{ One-Sample Test } \\
\cline { 2 - 5 } & \multicolumn{4}{|c|}{ Test Value $=10$} \\
\cline { 2 - 5 } & t & d & Sig & Mean & $\begin{array}{c}95 \% \\
\text { Confiden }\end{array}$ \\
\hline
\end{tabular}




\begin{tabular}{|c|c|c|c|c|c|c|}
\hline & & & \multirow[t]{2}{*}{$\begin{array}{l}\text { (2- } \\
\text { tail } \\
\text { ed) }\end{array}$} & \multirow[t]{2}{*}{$\begin{array}{l}\text { differ } \\
\text { ence }\end{array}$} & \multicolumn{2}{|c|}{$\begin{array}{c}\text { ce } \\
\text { interval } \\
\text { of the } \\
\text { Differenc } \\
\text { e }\end{array}$} \\
\hline & & & & & $\begin{array}{c}\text { Lo } \\
\text { we } \\
\text { r }\end{array}$ & $\begin{array}{l}\text { Up } \\
\text { per }\end{array}$ \\
\hline $\begin{array}{l}\mathrm{R} \\
\mathrm{O} \\
\mathrm{E}\end{array}$ & $\begin{array}{c}, 5 \\
01\end{array}$ & 8 & $\begin{array}{c}.63 \\
0\end{array}$ & ,914 & $\begin{array}{c}- \\
3,3 \\
0\end{array}$ & $\begin{array}{c}5,1 \\
3\end{array}$ \\
\hline
\end{tabular}

Sumber : data dioleh dengan SPSS v21

Berdasarkan hasil olahan SPSS diatas maka nilai t hitung untuk variabel Return On Equity adalah sebesar 0,501 kemudian nilai $t$ hitung tersebut akan dibandingkan dengan nilai $t$ tabel dengan derajat kebebasan $(\mathrm{dk})=\mathrm{n}-\mathrm{k}=9-1=8$ dan taraf kesalah $5 \%$ untuk uji satu pihak (one tail test) pihak kiri didapat nilai t tabel (pada daftar distribusi t) adalah sebesar 2.306. jika dibandingkan antara nilai $t$ tabel dangan $t$ hitung, maka $t$ tabel lebih besar dari pada $t$ hitung $(2.309 \geq 0,501)$ Sehingga jatuh pada daerah penerimaa $\mathrm{Ha}$ yang berarti Ha diterima dan Ho ditolak. Sehingga hal ini menjawab dan membuktikan hipotesis yang menyatakan bahwa " Return on Equity pada PT Adaro Energy Tbk kurang dari sama dengan 10\% dikatakan sehat. ini menunujukan kemampuan perusahaan dalam mengelola modal sendiri untuk menghasilkan laba sangat baik.

\subsection{Debt to Equity Ratio}

Dengan menggunakan Uji - $t$ test one sampel dengan nilai $\mu=10 \%$ serta tingkat signifikan 0,05 dapat dihitung sebagai berikut:

1. Standar Deviasi (s)

$$
\begin{aligned}
& S=\sqrt{\frac{\sum\left(X 1-\bar{X}^{2}\right.}{n-1}} \\
& S=\sqrt{\frac{5498}{9-1}}
\end{aligned}
$$

$$
\begin{aligned}
& S=\sqrt{\frac{5498}{8}} \\
& S=\sqrt{687,25} \\
& S=26.215
\end{aligned}
$$

\section{Uji-T}

Uji-T untuk satu sampel dalam istilah lain biasanya disebut dengan One Sample TTest Method, merupakan prosedur uji-t untuk sampel tunggal jika rata-rata suatu variabel tunggal dibandingkan dengan suatu nilai konstantan tertentu. Uji-t tersebut dapat dihitung dengan rumus sebagai berikut : Menghitung $t$ test one sample (Uji $\mathrm{T}$ ) adalah sebagai berikut:

$$
\begin{aligned}
& \mathrm{t} \text { hitung }=\frac{x-\mu 0}{\frac{s}{\sqrt{n}}} \\
& \mathrm{t} \text { hitung }=\frac{95,67-90}{\frac{26,125}{\sqrt{9}}} \\
& \mathrm{t} \text { hitung }=\frac{5,67}{8,733} \\
& \mathrm{t} \text { hitung }=0,650
\end{aligned}
$$

\begin{tabular}{|c|c|c|c|c|c|c|}
\hline & \multirow{2}{*}{\multicolumn{6}{|c|}{$\begin{array}{l}\text { One sample test } \\
\text { Test Value }=10\end{array}$}} \\
\hline & & & & & & \\
\hline & \multirow[t]{2}{*}{$\mathrm{t}$} & \multirow[t]{2}{*}{$\begin{array}{l}\mathrm{d} \\
\mathrm{f}\end{array}$} & \multirow[t]{2}{*}{$\begin{array}{l}\text { Sig. } \\
\text { (2- } \\
\text { tail } \\
\text { ed) }\end{array}$} & \multirow[t]{2}{*}{$\begin{array}{l}\text { Me } \\
\text { an } \\
\text { diff } \\
\text { ere } \\
\text { nce }\end{array}$} & \multicolumn{2}{|c|}{$\begin{array}{c}95 \% \\
\text { Confidence } \\
\text { interval of } \\
\text { the } \\
\text { Difference }\end{array}$} \\
\hline & & & & & $\begin{array}{c}\text { Lo } \\
w\end{array}$ & $\begin{array}{c}\text { Uppe } \\
\text { r }\end{array}$ \\
\hline $\begin{array}{c}\mathrm{DE} \\
\mathrm{R}\end{array}$ & $\begin{array}{c}, 65 \\
0\end{array}$ & 8 & $\begin{array}{c}.53 \\
4\end{array}$ & $\begin{array}{l}5,6 \\
73\end{array}$ & $\begin{array}{l}- \\
4,4\end{array}$ & $\begin{array}{c}25,8 \\
1\end{array}$ \\
\hline
\end{tabular}

Standar deviasi dan t hitung one sample test

\begin{tabular}{|c|c|c|c|c|}
\hline \multicolumn{5}{|c|}{ One sample statistic } \\
\hline & $\mathrm{N}$ & $\begin{array}{c}\text { Mea } \\
\mathrm{n}\end{array}$ & $\begin{array}{c}\text { Std. } \\
\text { Deviati } \\
\text { on }\end{array}$ & $\begin{array}{c}\text { Std.Err } \\
\text { or } \\
\text { Mean }\end{array}$ \\
\hline DER & 9 & $\begin{array}{c}95,67 \\
33\end{array}$ & $\begin{array}{c}26,200 \\
73\end{array}$ & $\begin{array}{c}8,7335 \\
8\end{array}$ \\
\hline
\end{tabular}

Sumber : data dioleh dengan SPSS v21

Sumber : data dioleh dgn SPSS V21 
Berdasarkan hasil olahan SPSS diatas maka nilai t hitung untuk variabel Return On Equity adalah sebesar 0,650 kemudian nilai t hitung tersebut akan dibandingkan dengan nilai $t$ tabel dengan derajat kebebasan $(\mathrm{dk})=\mathrm{n}-\mathrm{k}=9-1=8$ dan taraf kesalah $5 \%$ untuk uji satu pihak (one tail test) pihak kiri didapat nilai t tabel (pada daftar distribusi t) adalah sebesar 2.306. jika dibandingkan antara nilai $\mathrm{t}$ tabel dangan $t$ hitung, maka t tabel lebih besar dari pada $\mathrm{t}$ hitung $(2.309 \geq 0,650)$ Sehingga jatuh pada daerah penerimaa $\mathrm{Ha}$ yang berarti Ha diterima dan Ho ditolak. Sehingga hal ini menjawab dan membuktikan hipotesis yang menyatakan bahwa “ Debt to Equity Ratio pada PT Adaro Energy Tbk kurang dari sama dengan 90\% kali dikatakan baik. ini menunujukan kemampuan perusahaan dalam pengelolaan lebih mngedepankan modal sendiri dari pada hutang dari pihak ketiga sehingga berdampak semakin besar beban terhadap pihak luar.

\section{KESIMPULAN}

Berdasarkan hasil penelitian dan pembahasan yang telah diuraikan diatas maka dapat ditarik kesimpulan bahwa Return on Equity pada PT Adaro Energy Tbk yang diharapkan baik "diterima". dan Debt to Equity pada PT Adaro Energy Tbk yang di harapkan baik Ini menunujukan pengelolaan modal sendiri yang dilakukan oleh perusahaan sudah baik dan perusahaan lebih mengedepankan modal sendiri dari pada pinjaman dari luar atau pihak ketiga.

\section{SARAN}

Berdasarkan hasil penelitian yang telah dikemukakan diatas diajukan saran sebagai berikut :

1. Dalam melakukan usaha sebaiknya perusahaan lebih baik meminimalkan modal dari Luar dan lebih banyak menggunaka modal sendiri.

2. untuk dapat melakukan penelitian lebih lanjut mengenai Return On Equity dan Debt to Equity pada perusahaan yang berbeda. Hal ini berguna untuk menguji temuan faktor yang menyebabkan kredit bermasalah dalam penelitian ini secara lebih luas . dan menambahkan variabel lain seperti harga saham.

\section{DAFTAR PUSTAKA}

Adriani, Rizki, \& dkk. (2015). pengaruh current ratio,debt to Equity ratio,total aset turn over terhadap Return on Equity. jurnal admnistrasi bisnis, 25.

Armin, K. (2019). pengaruh Current Ratio dan Debt to Equity Ratio terhadap Return on Equity pada perusahaan Food and Baverage yang terdaftar di Indonesia Stock Exchange (IDX) tahun 20122016. Jurnal Media Wahana Ekonomika.

Fahmi, I. (2015). Analisis Laporan Keuangan. Bandung: Alfabeta.

Fatmawati. (2019). pengaruh kinerja keuangan dan ukuran perusahaan terhadap Harga saham . jurnal Febi, 19.

Fransiska. (2014). pengaruh return on equity, earning per share price earning ratio terhadap return saham pada perusahaan Barang konsumsi di BEI. Jurnal Akuntansi, 2, 1-8.

Ghozali. (2016). Aplikasi Analisis Multivariat dengan Program IBM SPSS. Semarang: Universitas Diponegoro.

Hani. (2015). Teknik Analisa Laporan Keuangan . Medan : UMSU PRESS

Hans. (2016). Akuntansi Keuagan Berdasarkan SAK berbasis IFRS. jakarta: IAI. 
Harahap. (2015). Analisis Kritis atas Laporan Keuangan . Jakarta : Rajawali Pers.

Hery. (2015). Analisa Laporan Keuangan. Yogyakarta: Center For Academic Publising Service.

Houston, \& Brigham, d. (2017). Dasar dasar Manajemen Keuangan. Jakarta: Salemba empat.

Hutahuruk. (2017). Zahir Accounting . Jakarta: Indeks.

IAI. (2015). Standar Akuntansi Keuangan ETAP. Jakarta: Ikatan Akuntan Indonesia.

Kasmir. (2016). Analisa laporan Keuangan. Jakarta: Raja grafindo persada.

Komalasari. (2017). pengaruh current ratio, debt to equity ratio, total aset turn over dan ukuran perusahan terhadap kinerja perusahaan pada Perusahaan makanan dan minuman di BEI. Perbanas.

Novita, \& Herlambang. (2020). pengaruh Net profit margin, debt to equity ratio dan inventory turnover terhadap harga saham pada perusahaan consumer goods industry yg terdaftar di bursa efek indonesi. Jurnal Owner.

Rahmawati, \& Suryono. (2017). Pengaruh DPR, EPS, dan DER terhadap Harga Saham. JUrnal Ilmu dan Riset Akuntansi.

Sugiyono. (2016). Metode Penelitian Kuantitatif, Kualitatif dan $R \& D$. Bandung : Alfabeta.

Syamsuddin, L. (2016). Manajemen Keuangan Perusahaan . Jakarta: Rajawali Pers.

Wulandari, \& Dkk. (2020). pengaruh ROE, CR, TATO, NPM terhadap Harga Saham Pada perusahaan Manufaktur Sub Costumer Goods yang terdaftar di Bursa Efek Indonesia. Jurnal Owner .

Yanti, \& Oktari. (2018). pengaruh tingkat Profitabilitas, Solvabilitas,
Ukuran Perusahaan dan Ukuran kantor Akuntan Publik pada Penundaan pemeikasaan (studi empiris pada perusahaan Manufaktur yang terdaftar di BEI tahun 2013-2016) . eCo-Buss, 1523.

Zainal, \& Marlius. (2018). Analisis Kinerja Keuangan Pada PT Pegadaian Cabang Ulak Karang. INA-RXiv Paper. 